\title{
SOME MUSING ON LOLLY WILLOWES A personal response to Rosemary Sykes' \\ paper The Willowes Pattern by Ren Draya
}

Rosemary Sykes' engaging talk on Lolly Willowes has prompted me to re-read and reconsider the novel. My musings here represent quite a preliminary exploration, and I present them in hope that this Journal can provide us with a forum for further inquiries and dialogue. I shall also try to provide some especially American "connections" to this wonderful novel.

Rosemary pointed out that Lolly is a product of family traditions, that there are proscribed canons of behaviour to which she must conform. We see her constricted, both at Lady Place and in London. As I contemplate Lolly, I find myself returning to Sylvia Townsend Warner's own diaries. A 1928 entry reads:

It was very hot and clear. I sat down under the plane-trees where Teague had refused to visit the Albert Memorial; and suddenly, I saw their trunks and branches all mottled and serpentine where they had cast away the works of darkness. This enraptured me into a seventh heaven within me; and I lay on my back looking at blue sky, red-gold and pure green leaves, lime-coloured new flesh and purple and tête de negre old, while the wind blew down happy days next year on to me and I was too certain of this present joy to mind trying to catch them. There like a bird I sat and sang. ... It was a moment for ever. Spring cannot bring me to the same ravishment. Spring is strictly sentimental, self-regarding; but I burn more careless in the autumn bonfire.(p.27) 
Just two years after the publication of Lolly Willowes! Are there diary entries from the times Warner was writing Lolly Willowes? Has Warner put some of her own passion for nature in her portrayal of Lolly? From a description of Lolly after she and the Willowes (her brother's family) have returned to London in the early autumn:

At these times she was subject to a peculiar kind of day-dreaming, so vivid as to be almost a hallucination: that she was in the country, at dusk, and alone, and strangely at peace . . . while her body sat before the first fires and was cosy with Henry and Caroline, her mind walked by lonely sea-bords, in marshes and fens, or came at nightfall to the edge of a wood.(p.76)

Is there here a tone, a response that links Warner directly to Lolly? Lolly, who "makes an appointment with the sunset that she should see it from top of a certain hill"(p.111). Of course, Warner's deft portraits of women-especially of single women no longer young-must surely be products of both her own experiences and her keen observations. "Happiness," a story from the collection Stranger with a Bag (1966: in U.S. Swans on an Autumn River), is an interesting example. In the story we find Lavinia Benton envisioning herself buying a country house. Her cousin Esther has died and has named Lavinia executor of her will; the house must be sold:

Suppose she bought the house? Not from sentiment, not from piety, not from resentment of bungalows, but for her own pleasure. She would keep her old bedroom, of course, smelling the pear blossom in the early morning, sharing bees with it, hearing a pear fall ...

Similarly,. Lolly, after the witches' sabbath, imagines living in "a cottage in a dell among the beechwoods":

She began to picture her life in such a cottage, thinking that it would be even better than lodging in the village. She imagined her white-washed bedroom full of moving green shades; the wood-smoke curling up among 
the trees; the majestic arms, swaying above her while she slept, and plumed with snow in winter.

Both Lavinia and Lolly picture a country cottage, their own room, a special tree-sadly, neither woman will ever occupy this idealized sanctuary.

"Magic is at the heart of Warner's work" (Miranda Seymour)

In a 1978 review published in the Times Literary Supplement, J.I.M. Stewart calls Lolly Willowes "as original in its conception as it is subtle and refined in its artistry." $\mathrm{He}$ places the novel in the context of works which feature magic characters-Ariel, fauns, the devil-and mentions the likes of E.M. Forster, Max Beerbohm, George Bernard Shaw (citing Jack Tanner's encounter with the devil in Man and Superman).

I recall Sylvia Townsend Warner's own delightful comment from "A Fragment," published in the first issue of this journal. Writing in the 1920 s (before, after, or during Lolly Willowes?) she said, "I think there is a great deal of pleasure and profit to be found by women who revive the old art of witchcraft..." That word, pleasure, appears in the excerpt from "Happiness" (above) and in the scene in Lolly Willowes with $\mathrm{Mr}$ Saunter and the chickens:

Laura had never become as clever with the birds as Mr Saunter. But when she had overcome her nervousness she managed them well enough to give herself a great deal of pleasure. They nestled against her, held fast in the crook of her arm, while her fingers probed among the soft feathers and rigid quills of their breasts. She liked to feel their acquiescence, their dependence upon her. She felt wise and potent.(p.146)

Like Lavinia Benton, Lolly's life has not afforded her much personal happiness nor opportunities for others to be dependent on her. Women's dependency is a favourite Warner motif. After all, as Lolly asserts in her long outpouring to Satan: 
Women have such vivid imaginations, and lead such dull lives. Their pleasure in life is soon over; they are so dependent upon others, and their dependence so soon becomes a nuisance...(p.234)

Again we feel the poignancy of that word-pleasure. Moments later, Lolly adds her realization:

One doesn't become a witch to run around being harmful, or run round being helpful either, a district visitor on a broomstick. It's to escape all that-to have a life of one's own, not an existence doled out to you by others...(p.239)

I wonder about this theme of witchcraft and the deal Lolly makes with the devil, and am prompted to imagine the dramatic intensity of Marlowe's Dr Faustus signing his soul away for twenty-four years of power and pranks. The encounter between Lolly's Nephew Titus and the wasps may well remind us of Faustus' invisible sparring with the Vatican cardinals! These connections lead me to think of the high-kicking Gwen Verdon in the American musical version of the Faustian story, Damn Yankees or of Stephen Vincent Benet's The Devil and Daniel Webster.

Many other American literary pieces feature Satan. Would Warner have been familiar with Nathaniel Hawthorne's brilliant short story, "Young Goodman Brown"? It, too, is set in a forest, at night; it culminates in a witches' meeting, although Hawthorne's is a black mass and the scene is painted in more lurid and frightening tones than the whirling dancers of Lolly Willowes. Like Lolly, Goodman Brown has a night-time encounter with the devil. Just as Lolly sees "ordinary" folk from Great Mop in the woods at night, so Brown meets a range of people from his community; just as Miss Larpent says slyly, "Long ago ... I had the pleasure of meeting your great-uncle, Commodore Willowes", so Brown is told that his family has long been "well acquainted" with the devil. Both Lolly and Brown hear unseen music, both talk to someone who immediately disappears, both are reassured by the devil that he can always be found, both succumb to drowsiness. 
Sylvia Townsend Warner's readers may enjoy a contemporary piece of American fiction, Marilynne Robinson's Housekeeping (1980). It is both realistic novel and a moral fable in the Lolly Willowes tradition: a freespirited aunt named Sylvie (person of the woods) becomes caretaker to her two nieces. Like Lolly, Sylvie's ways run counter to the rigid conventions of the surrounding society. Another American novelist, Alice Hoffman, gives us several variations of magic in Fortune's Daughter, Practical Magic, and Seventh Heaven: Nora Silk, divorced, is perceived as a witch by all her respectable neighbours-and some of Nora's actions are indeed downright witch-like.

Finally, all this talk of Satan tweaks me to play devil's advocate. Rosemary Sykes ended her paper with a statement that "Laura is carrying on life in her own way ..." and spoke of a kind of feminist triumph in Laura's becoming a witch. I wonder if there might also be a less cheery interpretation of the novel's conclusion. In a way, the females are destroyed: Fancy and Marion both lack any sparkle or imagination; Pandora will be installed at Lady Place and produce future Willowes to adhere to the family pattern. And Laura? Had the novel been entitled Laura Willowes, I might agree with Rosemary's optimism. True, once Lolly moves to Great Mop, Warner refers to her as Laura; it is Laura who becomes a witch, Laura who speaks to the devil, Laura who is told by him:

You are not my only conquest, and I am not a human master to have favourites among my servants. All are souls that come to my net . . (p.241)

But it is by the name of Lolly, the child-like and dependent family cast-off, that we know this novel.

There are some further reasons for my darker analysis of the final scene. Laura has accompanied Titus and Pandora to the train station, she has no way to get home. She dawdles, buys some fruit, climbs a hill. During her outpouring to Satan, the two overlook a grotesque cemetery. Satan reminds Laura that Mr Jones "will have his reward in another 
life"(p.242). I infer from this that Mr Jones will be damned forever. When a midge settles on Laura's wrist, she smacks at it. "Dead!" said Satan. Moments later, Laura asks, " 'Is it time?' He nodded, and smiled." I infer that Laura, like the midge, like Amy Cruttwell in Warner's 1935 (or earlier?) short story "The Property of a Lady," is ultimately insignificant. She, too, will soon be dead. When Laura gets up from the plot of grass, Satan has disappeared.

For a moment Laura thought that she had him: and on the next, as though he had tricked himself out of her grasp, her thoughts were scattered by the sudden consciousness of a sort of a jerk in the atmosphere. The sun had gone down, sliding abruptly behind the hills. In that case, the bus would have gone too, she might as well hope to catch the one as the other. First Satan, then the bus-adieu, mes gens! With affectionate unconcern she seemed to be waving them farewell, pleased to be left to herself, left to enter this new independence acknowledged by their departure.(p.246)

I do not think this "independence" will be more than a few hours long. Laura may find a "suitable dry ditch or an accommodatingly loosened haystack," or she may "penetrate into a wood and burrow herself a bed." These descriptions seem to be of a final resting place, a coffin. Laura realizes that Satan will not disturb her: "Why should he? The pursuit was over."

Note

All page references for Lolly Willowes are to the Virago edition (2000), which is offset from the Chatto \& Windus 1926 first edition. 